\title{
Pengaruh Inovasi Kelembagaan Pada Pengembangan Klaster Batik Laweyan Kota Surakarta
}

\author{
Ery Dyah Wulandari ${ }^{1}$ \\ Magister Pembangunan Wilayah dan Kota \\ Universitas Diponegoro, Semarang, Indonesia
}

\begin{abstract}
Abstrak: Klaster Batik Laweyan adalah salah satu klaster yang memiliki pertumbuhan signifikan yang ditunjukkan melalui inovasi kelembagaan di dalamnya. Hal ini dibuktikan dari kondisi perdagangan sebelum Laweyan dikembangkan serta adanya Forum Pengembangan Kampoeng Batik Laweyan yang mewadahi pengembangan klaster tersebut. Penelitian ini memunculkan pertanyaan "Bagaimana inovasi kelembagaan mempengaruhi pengembangan Klaster Batik Laweyan?”. Untuk menjawab pertanyaan penelitian tersebut, pendekatan penelitian yang digunakan adalah kualitatif dengan metode deskriptif kualitatif. Metode ini dipilih karena dapat mengkaji informasi yang dibutuhkan untuk menjawab sasaran penelitian secara mendalam. Data diperoleh melalui wawancara dan observasi lapangan. Analisis yang dilakukan menggunakan metode analisis deskriptif kualitatif untuk menganalisis tahapan perubahan pada Klaster Batik Laweyan dan invoasi kelembagaannya. Hasil penelitian ini menunjukkan bahwa ada pengaruh inovasi kelembagaan tersebut. Ini ditunjukkan dari tumbuhnya rasa kenyamanan dan kepercayaan dalam ikatan sosial yang terbentuk antara sesama anggota klaster, rasa diterima dan kesepakatan pada tujuan bersama Forum Pengembangan Klaster Batik Laweyan (FPKBL) sebagai norma baru dalam manajemen kelembagaan Batik Laweyan. Hal tersebut berpengaruh terhadap peningkatan jumlah anggota yang bekerjasama, inovasi dagang dan peningkatan upaya menciptakan iklim bisnis. Jaringan klaster tersebut juga tumbuh secara eksternal dengan agen perjalanan dan pariwisata, bidang akademis, swasta, LSM, dan pemerintah.
\end{abstract}

Kata Kunci: individu, inovasi, institusi, klaster, organisasi, sistem

\begin{abstract}
Klaster Batik Laweyan is one of the cluster experienced significant growth as indicated by the existence of institutional innovations in it. This is evident from the condition of the business in the previous Laweyan dim currently being developed due to the formation Forum Pengembangan Kampoeng Batik Laweyan the container in cluster development. This study raises the question "How do innovation institutions affect to the development of Klaster Batik Laweyan?". To answer this research question, the research approach used was qualitative descriptive survey method. This method was chosen because it can explore deeper into the information needed to answer the research objectives. Data was collected through interviews and field observations. The analysis was done by descriptive qualitative analysis method to the analysis stage changes Batik Laweyan Cluster and institutional innovation analysis. The results showed the influence of institutional innovation in the development of Batik Laweyan Cluster. This is indicated by the growing sense of comfort and trust in the new social ties between members of a cluster, among others, the receipt or agreement on common goals Forum Pengembangan Klaster Batik Laweyan (FPKBL) as an order or a new norm in institutional management Batik Laweyan. It was influential in the development of clusters as
\end{abstract}

\footnotetext{
1 Korespondensi Penulis: Magister Pembangunan Wilayah dan Kota, Universitas Diponegoro, Semarang
} Email: ery.dyah@gmail.com 


\section{Pengaruh Inovasi Kelembagaan Pada Pengembangan Klaster Batik Laweyan Kota Surakarta}

indicated by the increase in the capacity of members to collaborate, innovate business and increased efforts in Laweyan supporting emerging businesses. As well as the growing cluster networking externally with travel agencies and tourism, academic, private sector, NGOs and the government.

Keywords: clusters, innovation, institutions, individuals, organizations, systems

\section{Pendahuluan}

Perkembangan klaster sebagai salah satu strategi pengembangan ekonomi lokal tidak lepas dari adanya inovasi. Klaster menjadi wadah yang memungkinkan dalam mengembangkan inovasi, karena menurut Zuhal (2010) inovasi memungkinkan produk dan servis yang lebih baik, proses produksi yang lebih efisien dan bersih, serta meningkatkan efisiensi proses produksi yang pada gilirannya bakal meningkatkan model bisnis. Klaster Batik Laweyan merupakan salah satu klaster yang mengalami perkembangan signifikan yang diindikasikan karena adanya inovasi kelembagaan yang ada di dalamnya. Sebelum perkembangannya saat ini, Laweyan merupakan kawasan batik yang sudah hampir mati, karena para pengusaha mengalami kebangkrutan akibat kalah dengan industri batik printing. Bahkan di Laweyan sudah hampir tidak ditemukan proses pembuatan batik, banyak peralatan yang mangkrak tidak digunakan. Bangunan-bangunan rumah yang menjadi simbol kejayaan pada masa lalu juga tidak terawat lagi, bahkan banyak bagian bangunan yang dijual padahal bangunan rumah di Laweyan memiliki nilai sejarah karena bangunan rumah merupakan perpaduan antara rumah jawa kuno dan indische. Diindikasikan juga adanya kerusakan lingkungan terutama pencemaran sungai yang melewati Laweyan karena usaha batik yang masih berjalan membuang limbahnya langsung ke sungai.

Saat ini Laweyan mulai berkembang dengan terbentuknya sebuah forum yang bernama Forum Pengembangan Kampoeng Batik Laweyan. Terbentuknya forum ini menjadi titik balik perkembangan Klaster Batik Laweyan. Hal ini memunculkan keingintahuan tentang kronologi perubahan yang terjadi bagaimana ide baru dan perubahan yang dibawa oleh Ir. Alpha Fabela Priyatmono, MT bisa diterima oleh para pelaku usaha dan yang terpenting adalah apakah dengan inovasi kelembagaan tersebut mampu menyelesaikan permasalahan yang ada di Laweyan. Maka, pertanyaan penelitian yang muncul dari permasalahan tersebut adalah "Bagaimana inovasi kelembagaan berpengaruh pada pengembangan Klaster Batik Laweyan?”

Tujuan penelitian ini adalah untuk mengkaji inovasi kelembagaan dan pengaruhnya dalam pengembangan Klaster Batik Laweyan. Untuk mencapai tujuan penelitian tersebut dilakukan dengan sasaran yang pertama melakukan analisis perubahan Klaster Batik Laweyan dan yang kedua melakukan analisis inovasi kelembagaan yang terdiri dari analisis proses inovasi di tingkat individu baik pelaku usaha maupun pemangku kepentingan, analisis proses inovasi di tingkat organisasi dalam Klaster Batik Laweyan dan analisis proses inovasi dalam sistem kelembagaan Klaster Batik Laweyan.

\section{Metode Penelitian}

Pendekatan penelitian yang digunakan adalah pendekatan kualitatif deskriptif dengan metode survei. Hal ini berdasarkan pertimbangan bahwa pendekatan dan metode penelitian yang dipilih dapat digunakan untuk mencapai tujuan penelitian karena dengan metode survei dapat mengambil data yang bersifat kualitatif sehingga dapat lebih mendeskripsikan tentang inovasi kelembagaan dan pengaruhnya pada pengembangan Klaster Batik Laweyan. Pengumpulan data dilakukan dengan wawancara dan observasi lapangan. Wawancara yang akan dilakukan adalah dengan wawancara sistematik, yang 
menurut Bungin (2006) adalah wawancara yang dilakukan dengan terlebih dahulu pewawancara mempersiapkan pedoman tertulis tentang apa yang hendak ditanyakan kepada responden. Wawancara ini akan dilakukan pada para pengusaha industri batik di Klaster Batik Laweyan dan pemangku kepentingan terkait.

Untuk menentukan pemangku kepentingan yang akan dituju dilakukan dengan dua cara yaitu purposive sampling dan snowball sampling. Purposive sampling menurut Sugiyono (2008) adalah teknik penentuan sampel berdasarkan pertimbangan tertentu, yang digunakan untuk menentukan pemangku kepentingan dari populasi pengusaha batik di Klaster Batik Laweyan, sedangkan snowball sampling adalah teknik penentuan sampel yang mula-mula jumlahnya kecil, kemudian membesar (Sugiyono, 2008), yang digunakan untuk mendapatkan aktor-aktor kunci di tingkat organisasi yang berperan dalam pengembangan Klaster Batik Laweyan.

Untuk mencapai tujuan penelitian ini, penulis menggunakan metode penelitian kualitatif dalam melakukan analisis. Hal ini seperti yang diungkapkan oleh Moleong dalam Septiningrum (2010) bahwa penelitian kualitatif digunakan untuk memahami fenomena yang dialami oleh subjek penelitian, misalnya perilaku, persepsi, motivasi, tindakan, dan lain-lain. Pemilihan metode kualitatif juga didasarkan pada tujuan penelitian ini yang akan banyak menggali informasi dari orang per orang karena salah satu analisisnya adalah terkait dengan individu yaitu bagaimana individu dalam penelitian ini menerima inovasi dan melihat perubahan perilaku individu tersebut setelah adanya inovasi. Analisis akan dilakukan dalam beberapa tahap sebagai berikut:

- Analisis perubahan Klaster Batik Laweyan

Analisis ini akan melihat proses perubahan di Klaster Batik Laweyan dari tahun ke tahun. Perubahan tersebut akan digambarkan mulai dari sebelum tahun 2004, tahun 2004 dan setelah tahun 2004 yang merupakan momentum perubahan.

- Analisis Inovasi Kelembagaan

Analisis inovasi kelembagaan yang akan dikaji di sini terdiri dari tiga tahapan analisis yaitu:

- Analisis proses inovasi di tingkat individu baik pelaku usaha maupun pemangku kepentingan.

Analisis ini terkait dengan proses penerimaan individu terhadap inovasi, bagaimana terjadinya transfer knowledge dan mengkaji perubahan yang terjadi pada individu dalam melakukan usaha.

- Analisis proses inovasi di tingkat organisasi dalam Klaster Batik Laweyan.

Analisis di tingkat organisasi ini akan mengkaji tentang adopsi inovasi dalam organisasi baik terkait dengan struktur organisasi, program kerja, dinamika organisasi, perilaku berorganisasi dan dalam membentuk kreasi organisasi.

- Analisis proses inovasi dalam sistem klaster Batik Laweyan.

Analisis ini merupakan rangkaian dari analisis sebelumnya, yang bertujuan untuk mengkaji inovasi dalam sistem klaster dengan melihat bentuk-bentuk kerjasama antar organisasi, bentuk klaster dan adanya kebijakan dalam pengembangan usaha.

\section{Potensi dan Masalah Klaster Batik Laweyan}

Klaster Batik Laweyan terletak di Kecamatan Laweyan Kota Surakarta, dan memiliki luas wilayah 248 hektar. Kelurahan Laweyan sendiri berbatasan dengan Kelurahan Sondakan di sebelah utara, Kelurahan Bumi di sebelah timur dan Kelurahan Pajang di sebelah barat, sedangkan sebelah selatan langsung berbatasan dengan Kabupaten Sukoharjo. Batik yang menjadi industri utama di Laweyan, tersebar hampir di seluruh wilayah Laweyan yang terbagi dalam tiga RW dan delapan dukuh yaitu Kwanggan, Sayangan Kulon, Sayangan 


\section{Pengaruh Inovasi Kelembagaan Pada Pengembangan Klaster Batik Laweyan Kota Surakarta}

Wetan, Kramat, Seono, Kidul Pasar, Lor Pasar dan Klaseman. Persebaran industri batik Laweyan dan letaknya dapat dilihat dalam gambar peta Klaster Batik Laweyan berikut:

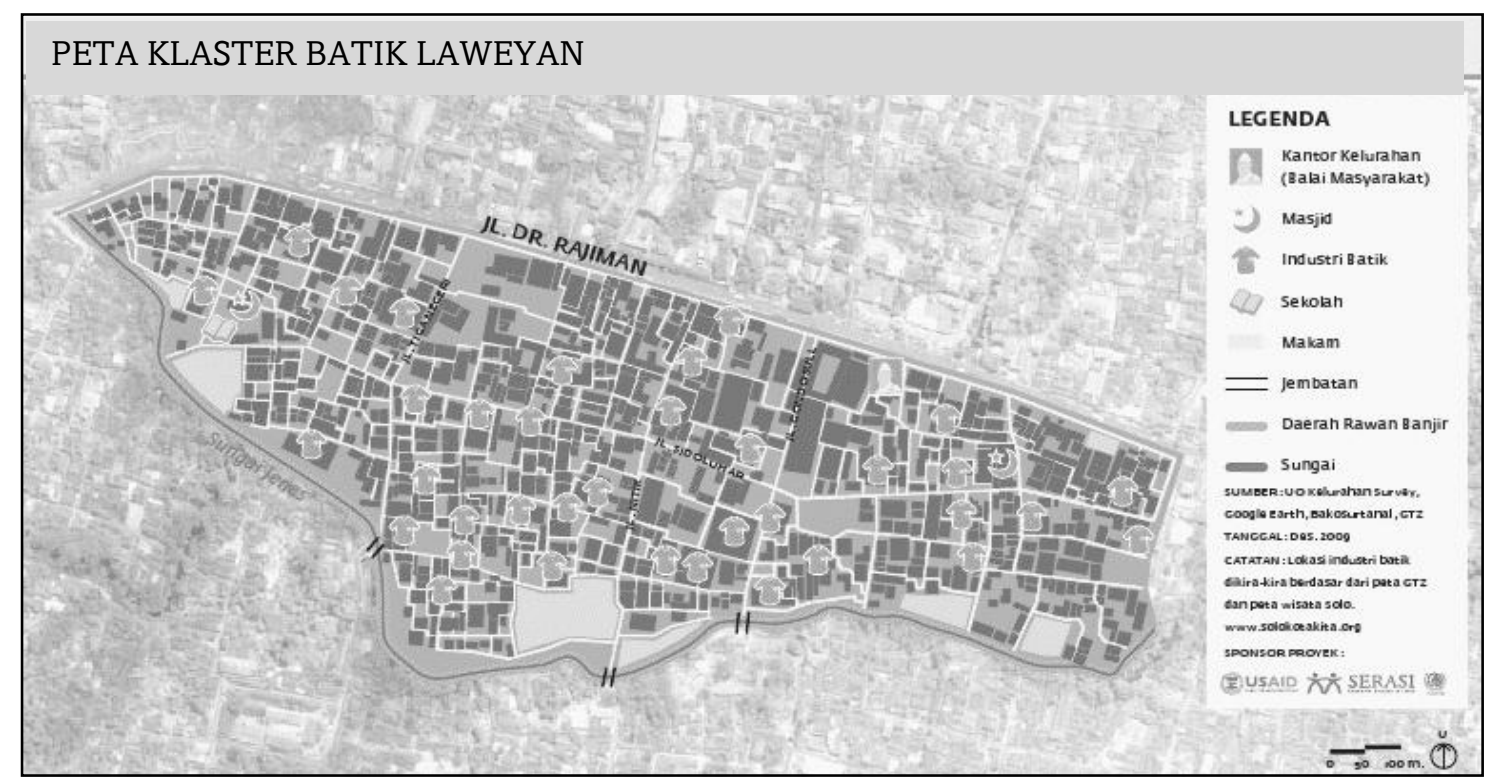

Sumber: solokotakita.org, diunduh 25 Desember 2011

\section{Gambar 1. Klaster Batik Laweyan}

Potensi Klaster Batik Laweyan yang pertama adalah adanya industri batik yang sudah ada sejak jaman dulu dan masih bertahan hingga sekarang walaupun mengalami pasang surut. Proses pembatikan dilakukan dengan dua cara yaitu batik tulis dan batik cap, setelah itu baru dilakukan proses pewarnaan. Batik yang dihasilkan memiliki berbagai motif ada yang motif lama seperti udanliris dan ada juga motif hasil dari kreatifitas pengusaha batik. Produk yang dihasilkan berupa bahan setengah jadi yaitu kain batik dan bahan jadi seperti baju batik dan sarung batik. Pemasaran produk-produk ini biasanya langsung dijual di showroom-showroom milik pengusaha dan ada juga yang sudah memiliki langganan untuk dipasarkan di luar Kota Surakarta.
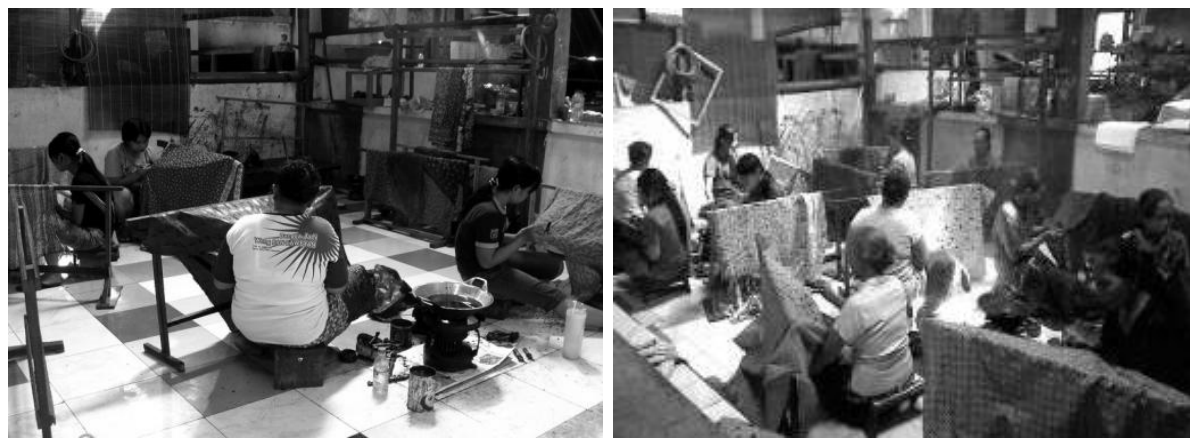

Sumber: triptourism.com

Gambar 2. Suasana Produksi Batik Tulis 


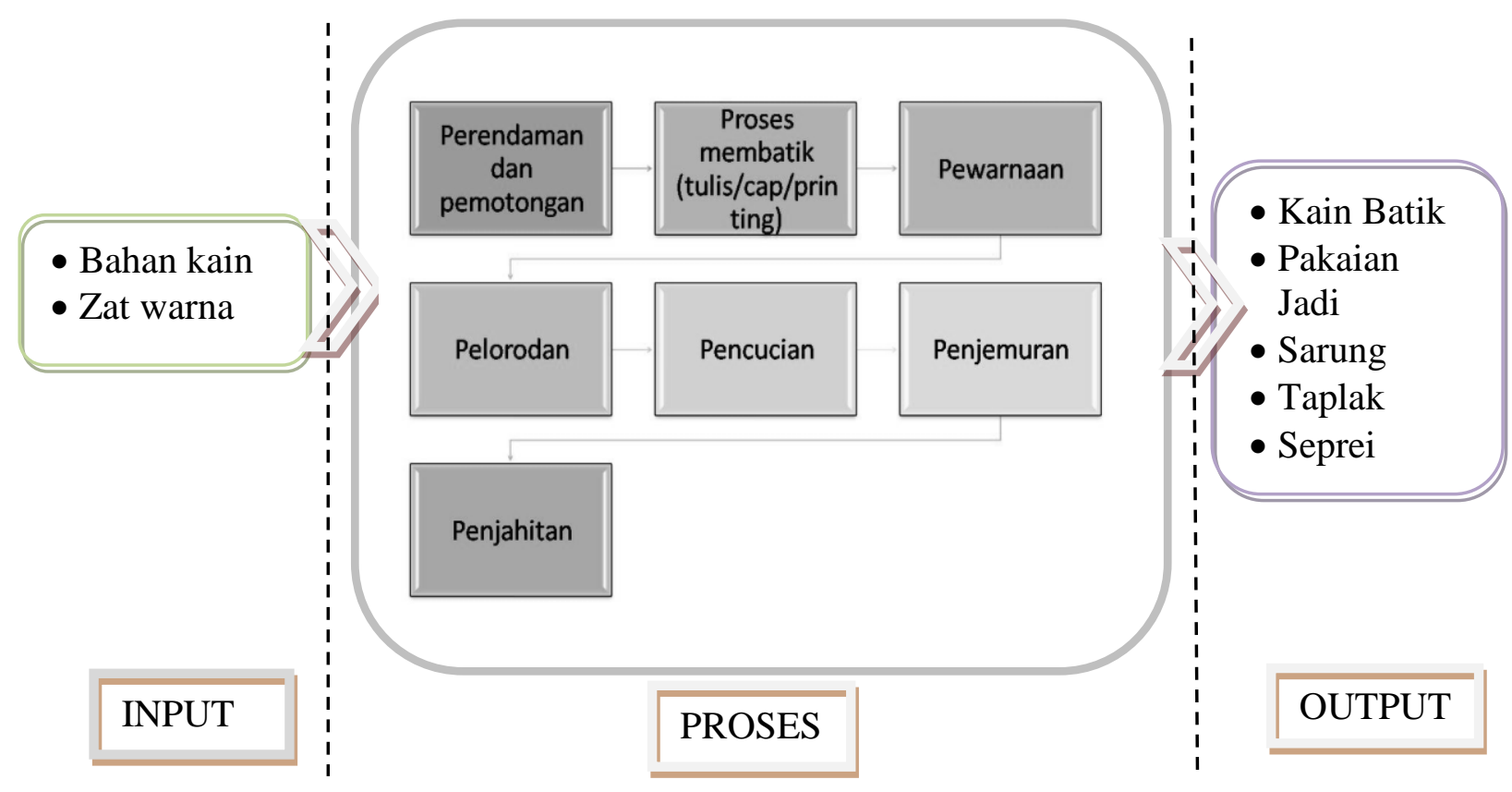

\section{Gambar 3. Proses Produksi Batik}

Potensi yang kedua adalah adanya bangunan-bangunan yang memiliki nilai sejarah yaitu bangunan peninggalan pada masa kejayaan industri batik pada jaman dahulu. Sejarah Kampung Laweyan dimulai sejak masa Kerajaan Pajang sekitar tahun 1546 M. Laweyan berasal dari kata Lawe (bahan sandang) karena telah menjadi pusat perdagangan bahan sandang seperti kapas dan aneka kain. Laweyan semakin pesat ketika Kyai Ageng Henis bermukim di Laweyan, beliau adalah putra dari Kyai Ageng Selo yang merupakan keturunan raja Brawijaya V. Beliaulah yang memperkenalkan seni membatik kepada santrisantrinya. Sehingga seni membatik ini menyebar dan menjadi ciri khas masyarakat Laweyan.
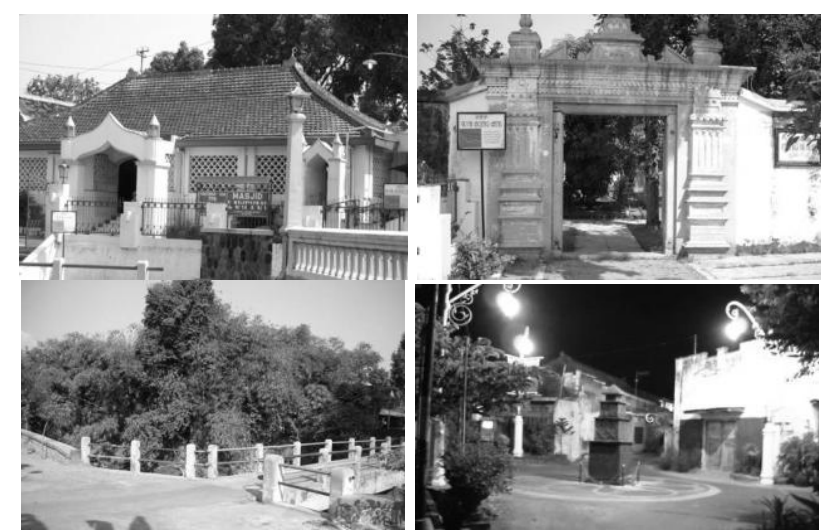

Sumber: http://www.kampoenglaweyan.com/id/index.php

\section{Gambar 4. Bangunan Peninggalan pada Masa Kyai Ageng Henis}

Dalam mengembangkan Klaster Batik Laweyan ini juga masih mengalami beberapa permasalahan yang dihadapi. Permasalahan tersebut antara lain adalah faktor individu dari pengusaha batik yang menempatkan dirinya sebagai juragan yang memiki otoritas sendiri 


\section{Pengaruh Inovasi Kelembagaan Pada Pengembangan Klaster Batik Laweyan Kota Surakarta}

dan terbiasa mengatur para pegawainya sehingga jika diatur atau diarahkan orang lain menjadi agak susah. Permasalahan yang lain adalah adanya kesenjangan antara usaha yang besar dan kecil, kesenjangan ini masih terasa karena berkaitan dengan modal dan belum adanya kerjasama untuk saling membantu dalam usaha agar dapat mengurangi kesenjangan tersebut. Berbagai akses informasi maupun kunjungan yang saat ini banyak masuk ke Laweyan sebagian besar lebih banyak dinikmati oleh usaha-usaha yang sudah besar. Pengunjung yang datang ke Laweyan biasanya diarahkan ke usaha-usaha yang besar sehingga usaha-usaha yang kecil menjadi semakin terpinggirkan.

\section{Inovasi Kelembagaan dalam Klaster}

\section{Pengertian dan Karakteristik Klaster}

Klaster menjadi salah satu strategi yang digunakan dalam mengembangkan ekonomi lokal. Menurut Porter (1998) klaster merupakan konsentrasi geografis antara perusahaan dan institusi penunjang yang saling berkaitan dalam satu lokasi, yang merupakan keterkaitan antar industri dan faktor penunjang yang lain sebagai strategi untuk menciptakan daya saing. Menurut Andersson, dkk (2004) klaster digambarkan sebagai sebuah proses dari suatu perusahaan dan aktor lain yang lokasinya terkonsentrasi dalam satu area geografis, saling bekerjasama dalam fungsi tertentu dan membangun sebuah pertalian usaha serta membentuk persekutuan untuk meningkatkan daya saing mereka secara kolektif. Berdasarkan pengertian di atas bahwa di dalam klaster ada suatu sistem kerjasama dan keterlibatan antar aktor. Hal itulah yang disebut dengan kelembagaan dalam istilah yang lain, karena menurut Rustiadi (dalam Septiningrum, 2010) kelembagaan adalah sekumpulan aturan main (rules of game) dan tata cara yang berperan dalam pengaturan dan pengalokasian sumber daya secara efisien dan berkelanjutan. Aktor-aktor yang terlibat di dalam klaster dapat dilihat dalam gambar berikut:

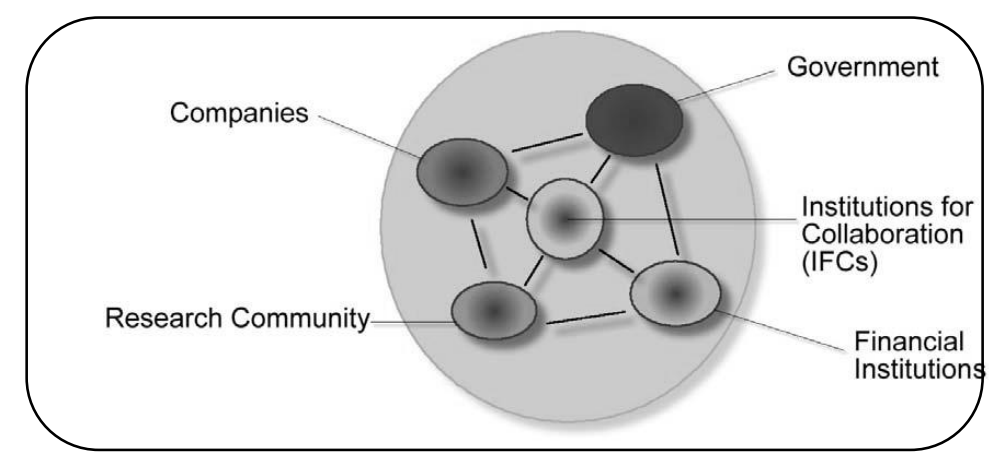

Sumber: Andersson, dkk (2004)

\section{Gambar 5. Aktor yang Terlibat dalam Klaster}

Selain adanya aktor yang terlibat dalam klaster, salah satu unsur klaster yang lain adalah adanya pertalian usaha. Bentuk pertalian usaha dalam klaster ini lebih dikenal dengan rantai nilai atau value chain. Rantai nilai menggambarkan berbagai kegiatan yang diperlukan untuk membawa produk atau layanan dari konsepsi, melalui berbagai tahapan produksi (melibatkan kombinasi transformasi fisik dan masukan dari berbagai layanan produser), pengiriman ke konsumen akhir, dan terakhir pembuangan setelah digunakan (Kaplinsky \& Morris, 2000). Rantai nilai tersebut digambarkan dalam skema yang dapat dilihat pada Gambar berikut: 


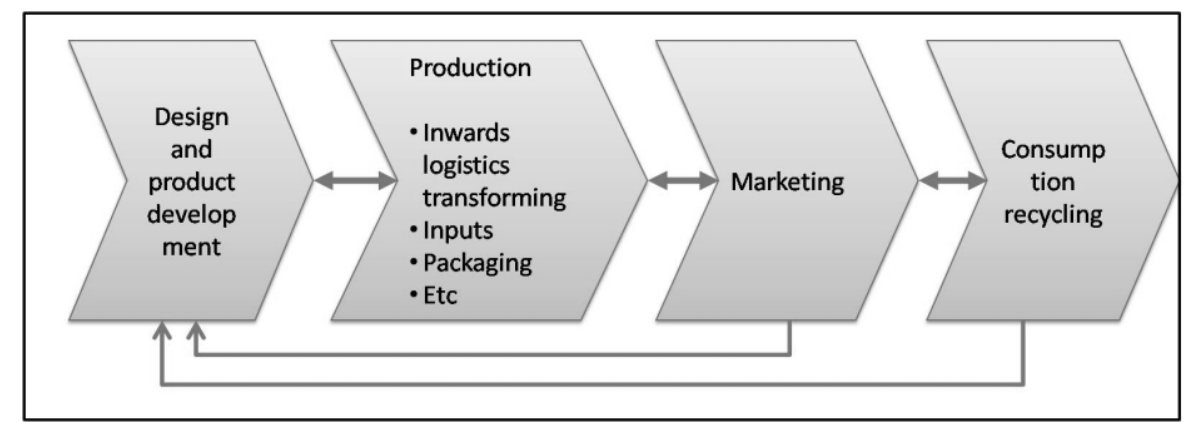

Sumber: Kaplinsky \& Morris, 2000

\section{Gambar 6. Skema Rantai Nilai}

Rantai nilai dalam pengertian yang lebih sederhana dimaknai sebagai urutan kegiatan yang diperlukan untuk membuat produk atau menyediakan layanan (Schmitz, 2005). Pemahaman rantai nilai dalam penelitian ini akan digunakan dalam melakukan analisis pengaruh inovasi kelembagaan pada Klaster Batik Laweyan, yaitu melihat pengaruh inovasi pada masing-masing mata rantai.

\section{Inovasi dalam Klaster}

Inovasi yang lahir dari perkembangan ilmu pengetahuan ini memiliki beberapa pengertian di antaranya adalah inovasi diartikan sebagai pemahaman tentang kreasi baru yang memiliki pengaruh signifikan dalam perekonomian (OECD, 2001). Inovasi memiliki peran yang strategis di era knowledge based economy (KBE) karena menurut Zuhal (2010) inovasi memungkinkan produk dan servis yang lebih baik, proses produksi yang lebih efisien dan bersih, serta meningkatkan efisiensi proses produksi yang pada gilirannya bakal meningkatkan model bisnis. Proses inovasi yang terjadi pada suatu industri meliputi bagaimana suatu barang diproduksi dan apa yang diproduksi, jadi inovasi dapat dilakukan pada produk dan proses. Inovasi dalam produk dapat berupa inovasi produk dan pelayanan, sedang inovasi dalam proses dapat berupa inovasi teknologi atau organisasi (OECD, 2001). Berdasarkan hal tersebut melahirkan bentuk - bentuk inovasi yang terlihat dalam Gambar 7

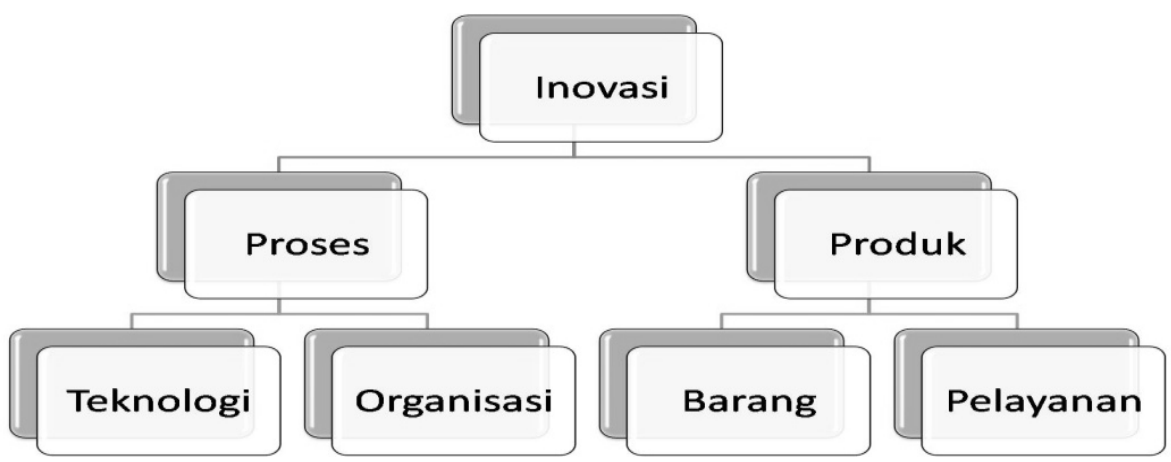

Sumber: OECD, 2001

\section{Gambar 7. Bentuk-Bentuk Inovasi}

Menurut Andersson, dkk (2004) klaster yang inovatif didorong oleh tiga daya dorong yaitu: 1) kreasi baru perusahaan dan diversifikasi teknologi (new firm creation and 
technological diversification); 2) kreasi hubungan antar aktor (inter-actor network creation); dan 3) bentuk klaster (cluster formation), seperti yang terlihat dalam gambar berikut:

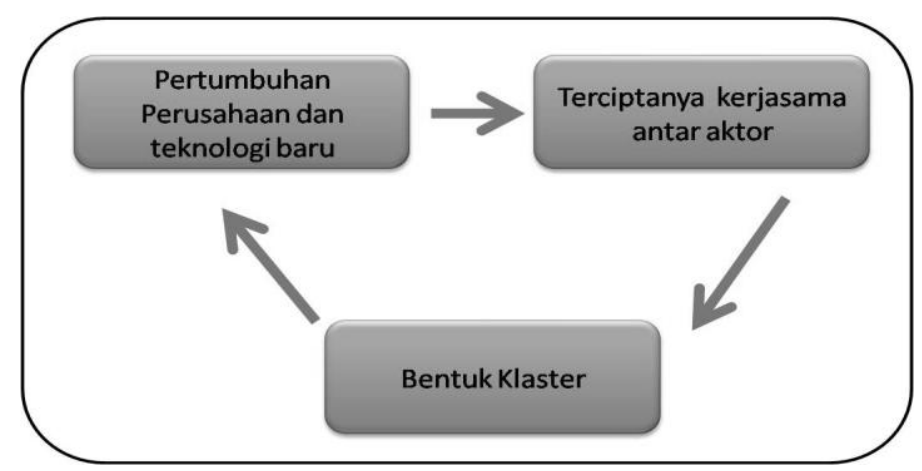

Sumber: Anderson, dkk, 2004

\section{Gambar 8. Daya Dorong Inovasi dalam Klaster}

Inovasi kelembagaan yang akan dibahas dalam penelitian ini akan merujuk pada tiga tingkatan yaitu inovasi di tingkat individu, organisasi dan sistem. Hal ini berdasarkan pemahaman bahwa inovasi merupakan salah satu bentuk peningkatan kapasitas. Dalam penerapan inovasi tentu dipengaruhi oleh faktor-faktor tertentu dalam mengambil keputusan. Hal ini karena inovasi merupakan hal baru yang membutuhkan kesiapan untuk gagal atau berhasil diterapkan, karena biasanya sesuatu yang baru yang belum ada pembuktian kebenarannya atau keberhasilannya masih diragukan oleh sebagian orang. Demikian sebaliknya inovasi ini akan menjadi mudah untuk diadopsi oleh pihak lain setalah adanya bukti keberhasilan. Beberapa faktor yang mempengaruhi proses keputusan inovasi menurut Rogers (dalam Trimurti, 2010) dapat dilihat dalam Tabel 1.

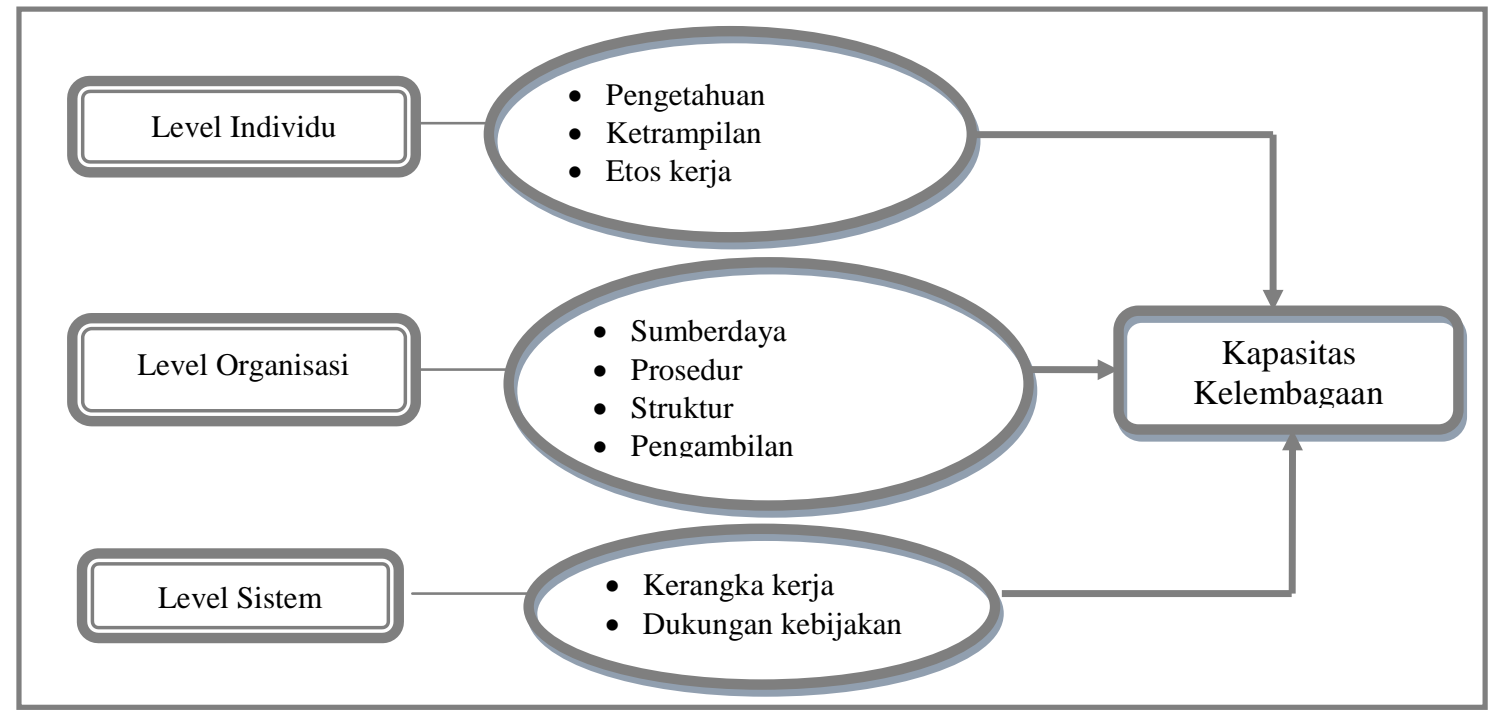

Sumber: Diadopsi dari Rohdewohld, 2004

\section{Gambar 9. Kapasitas Kelembagaan}


Tabel 1. Empat Faktor yang Mempengaruhi Proses Keputusan Inovasi

\begin{tabular}{|c|c|c|}
\hline No & Faktor & Penjelasan \\
\hline 1 & $\begin{array}{l}\text { Struktur Sosial } \\
\text { (social Structure) }\end{array}$ & $\begin{array}{l}\text { Struktur sosial adalah susunan suatu unit sistem yang memiliki pola } \\
\text { tertentu. Struktur ini memberikan keteraturan dan stabilitas perilaku setiap } \\
\text { individu (unit) dalam suatu sistem sosial tertentu. Struktur sosial juga } \\
\text { menunjukkan hubungan antar anggota dari sistem sosial. Hal ini dapat } \\
\text { dilihat dari struktur organisasi suatu perusahaan atau struktur sosial } \\
\text { masyarakat suku tertentu. Penelitian yang dilakuakan oleh rogers dan } \\
\text { kincaid di korea menunjukkan bahwa adopsi suatu inovasi dipengaruhi } \\
\text { oleh karakteristik individu dan juga sistem sosial tempat individu tersebut } \\
\text { berada }\end{array}$ \\
\hline 2 & $\begin{array}{l}\text { Sistem Norma } \\
\text { (System norms) }\end{array}$ & $\begin{array}{l}\text { Norma adalah suatu pola perilaku yang dapat diterima oleh semua anggota } \\
\text { sistem sosial yang berfungsi sebagai panduan atau standar bagi semua } \\
\text { anggota sistem sosial. Sistem norma juga dapat menjadi faktor } \\
\text { penghambat untuk menerima suatu ide baru. Hal ini sangat berhubungan } \\
\text { dengan derajat kesesuaian (compatibility) inovasi dengan nilai atau } \\
\text { kepercayaan masyarakat dalam suatu sistem sosial. Jadi, derajat } \\
\text { ketidaksesuaian suatu novasi dengan kepercayaan atau nilai-nilai yang } \\
\text { dianut oleh individu (sekelompok masyarakat) dalam sustu sistem sosial } \\
\text { berpengauh terhadap penerimaan suatu inovasi }\end{array}$ \\
\hline 3 & $\begin{array}{l}\text { Pemimpin opini } \\
\text { (opinion leader) }\end{array}$ & $\begin{array}{l}\text { Pemimpin opini yaitu orang-orang tertentu yang mampu mempengaruhi } \\
\text { sikap orang lain dalam suatu sistem sosial. Pemimpin opini dapat menjadi } \\
\text { pendukung inovasi atau sebaliknya, menjadi penentang. Ia (mereka) } \\
\text { berperan sebagai model dimana perilakunya (baik mendukung atau } \\
\text { menentang) diikuti oleh para pengikutnya. Jadi, pemimpin opini } \\
\text { memainkan peran dalam proses keputusan inovasi }\end{array}$ \\
\hline 4 & $\begin{array}{l}\text { Agen peubah } \\
\text { (agent of change) }\end{array}$ & $\begin{array}{l}\text { Agen peubah, hampir sama dengan pemimpin opini, mereka sama-sama } \\
\text { orang yang mampu mempengaruhi sikap orang lain untuk menerima suatu } \\
\text { inovasi. Agen peubah lebih bersifat formal yang ditugaskan oleh suatu } \\
\text { agen tertentu untuk mempengaruhi kliennya. Agen peubah adalah orang- } \\
\text { orang profesional yang telah mendapatkan pendidikan dan pelatihan } \\
\text { tertentu untuk mempengaruhi kliennya. Kemampuan dan ketrampilan } \\
\text { agen peubah berperan besar terhadap diterima atau ditolaknya inovasi } \\
\text { tertentu. }\end{array}$ \\
\hline
\end{tabular}

Sumber: Rogers dalam Trimurti, 2010

\section{Pengaruh Inovasi Kelembagaan Pada Pengembangan Klaster Batik Laweyan}

\section{Analisis Perubahan Klaster Batik Laweyan}

Klaster Batik Laweyan yang lebih dikenal dengan nama Kampoeng Batik Laweyan saat ini mengalami perkembangan yang pesat. Perubahan ini terjadi setelah tahun 2004 yaitu setelah berdirinya sebuah lembaga yang menjadi pendorong perubahan di Laweyan yang saat ini kembali dikenal sebagai salah satu pusat batik di Solo. Lembaga tersebut adalah FPKBL yaitu Forum Pengembangan Kampoeng Batik Laweyan. Sebelum terjadi perubahan seperti saat ini Klaster Batik Laweyan sempat mengalami kondisi mati suri yaitu antara tahun 1970-an sampai dengan tahun 2000, padahal dalam sejarahnya Laweyan sudah dikenal sebagai kampung batik karena kejayaan para pembatik yaitu di era tahun 1546 pada zaman Kerajaan Pajang dan di awal abad ke 20. Perubahan kondisi Klaster Batik Laweyan dari tahun ke tahun dapat dilihat dalam tabel berikut: 
Tabel 2. Kondisi Klaster Batik Laweyan dari Tahun ke Tahun

\begin{tabular}{|c|c|c|c|c|c|}
\hline Tahun & 1970-2000 & $2000-2003$ & 2004 & \multicolumn{2}{|c|}{2005 - Sekarang } \\
\hline Peristiwa & $\begin{array}{l}\text { - Kondisi } \\
\text { Laweyan } \\
\text { mati suri, } \\
\text { aktivitas } \\
\text { membatik } \\
\text { hampir tidak } \\
\text { ada } \\
\text { - Banyak } \\
\text { usaha batik } \\
\text { yang } \\
\text { bangkrut dan } \\
\text { tutup } \\
\text { - Bangunan } \\
\text { kuno milik } \\
\text { saudagar } \\
\text { batik tidak } \\
\text { terawat, } \\
\text { kumuh dan } \\
\text { rusak, } \\
\text { bahkan } \\
\text { beberapa } \\
\text { bagian } \\
\text { bangunan } \\
\text { ada yang } \\
\text { dijual }\end{array}$ & $\begin{array}{l}\text { - Mulai ada } \\
\text { gagasan dari } \\
\text { kaum muda } \\
\text { Laweyan untuk } \\
\text { membangkitkan } \\
\text { Laweyan dengan } \\
\text { konsep wisata } \\
\text { batik } \\
\text { - Tokoh muda } \\
\text { tersebut diketuai } \\
\text { oleh Bapak } \\
\text { Alpha Fabela } \\
\text { Priyatmono } \\
\text { - Tindakan yang } \\
\text { dilakukan adalah } \\
\text { mempersiapkan } \\
\text { kembali } \\
\text { produksi batik } \\
\text { walaupun } \\
\text { dengan dana } \\
\text { pinjaman } \\
\text { - Tindakan yang } \\
\text { kedua adalah } \\
\text { membuat konsep } \\
\text { wisata heritage } \\
\text { dan diajukan ke } \\
\text { Pemerintah Kota } \\
\text { Solo }\end{array}$ & $\begin{array}{l}\text { - Terbentuk } \\
\text { Forum } \\
\text { Pengembangan } \\
\text { Kampoeng } \\
\text { Batik Laweyan } \\
\text { (FPKBL) } \\
\text { - Pencanangan } \\
\text { Laweyan } \\
\text { sebagai } \\
\text { Kampoeng } \\
\text { Batik dan } \\
\text { memberikan } \\
\text { payung hukum } \\
\text { terhadap karya } \\
\text { cipta batik oleh } \\
\text { Pemerintah } \\
\text { Kota Solo } \\
\text { Pembangunan } \\
\text { Tugu Laweyan } \\
\text { sebagai } \\
\text { penanda } \\
\text { Kampoeng } \\
\text { Batik Laweyan }\end{array}$ & $\begin{array}{l}\text { - Pembangunan } \\
\text { berbagai } \\
\text { fasilitas } \\
\text { seperti shelter, } \\
\text { ornamen, } \\
\text { lampu hias, } \\
\text { papan } \\
\text { informasi dan } \\
\text { pagar tanaman } \\
\text { tahun 2007 } \\
\text { - Pembangunan } \\
\text { IPAL untuk } \\
\text { mengatasi } \\
\text { pencemaran } \\
\text { sungai di } \\
\text { Laweyan } \\
\text { (2006-2007) } \\
\text { Dibangunnya } \\
\text { Museum H. } \\
\text { Samanhudi } \\
\text { oleh Yayasan } \\
\text { Warna Warni } \\
\text { (2008) } \\
\text { Dimulainya } \\
\text { renovasi } \\
\text { rumah kuno di } \\
\text { Laweyan, } \\
\text { (2010) }\end{array}$ & $\begin{array}{l}\text { - Pengusaha batik } \\
\text { kembali } \\
\text { menjalankan } \\
\text { produksi dan } \\
\text { usaha batik } \\
\text { - Laweyan } \\
\text { sebagai } \\
\text { Kampoeng } \\
\text { Batik mulai } \\
\text { banyak dikenal } \\
\text { masyarakat luas } \\
\text { - Banyak } \\
\text { pegunjung } \\
\text { berdatangan } \\
\text { untuk berwisata } \\
\text { batik, baik } \\
\text { pengunjung dari } \\
\text { dalam maupun } \\
\text { luar negeri. } \\
\text { Banyak } \\
\text { pelatihan yang } \\
\text { ditujukan } \\
\text { kepada } \\
\text { pengusaha batik } \\
\text { Muncul usaha- } \\
\text { usaha } \\
\text { pendukung } \\
\text { seperti hotel, } \\
\text { restoran, } \\
\text { homestay }\end{array}$ \\
\hline
\end{tabular}

\section{Analisis Inovasi Kelembagaan}

Perubahan yang terjadi di Laweyan seperti yang telah diungkapkan pada pembahasan sub bab sebelumnya memberikan gambaran bahwa di balik perubahan yang terjadi ada campur tangan kelembagaan yang berperan. Campur tangan kelembagaan dalam pengembangan Klaster Batik Laweyan ini diindikasikan merupakan bentuk inovasi yang baru. Kelembagaan yang berperan dalam perubahan Klaster Batik Laweyan ini adalah dengan terbentuknya Forum Pengembangan Kampoeng Batik Laweyan. Hal ini didorong oleh peranan aktor yang mampu memberi pengaruh untuk melakukan perubahan. Terlihat dari inisiatif yang muncul dari tokoh muda Laweyan yang ingin mengembalikan kejayaan Laweyan seperti dulu. Ungkapan tersebut disampaikan oleh Alpha Fabela Priyatmono dalam wawancaranya dengan penyusun bahwa awal mula perubahan yang terjadi di Laweyan ini adalah adanya rasa prihatin dari tokoh masyarakat disini. Jika dikaitkan dengan penjelasan yang diungkapkan oleh Rogers, faktor utama yang mempengaruhi inovasi di Laweyan adalah adanya pemimpin opini dan agen peubah yaitu tokoh-tokoh yang tergabung dalam Forum Pengembangan Kampoeng Batik Laweyan. 


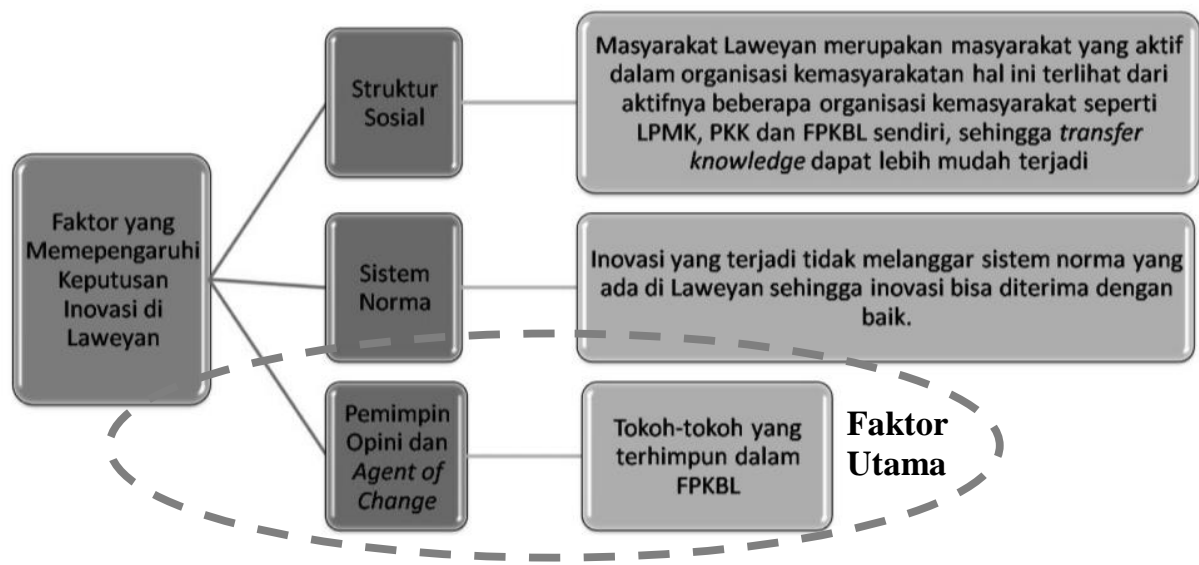

Gambar 10. Faktor yang Mempengaruhi Keputusan Inovasi di Laweyan

Terbentuknya Forum Pengembangan Kampoeng Batik Laweyan secara bertujuan untuk membangun serta mengoptimalkan seluruh potensi Laweyan untuk bangkit kembali dan menyiapkan diri dalam menghadapi tantangan globalisasi, dibangun dengan membuat jaringan dengan berbagai pihak baik pemerintah, akademis, LSM maupun swasta. Jaringan itu dibuat juga dalam rangka membuka pasar sehingga akan ada pelanggan baru dan mampu mendatangkan wisatawan ke Kampoeng Batik Laweyan. Adanya kerjasama tersebut juga diwujudkan dalam program-program seperti pelatihan, pameran, kunjungan wisata, kunjungan studi, penelitian dan bahkan memberikan bantuan dana dan peralatan. Jaringan yang terbentuk dapat dilihat dalam gambar berikut:

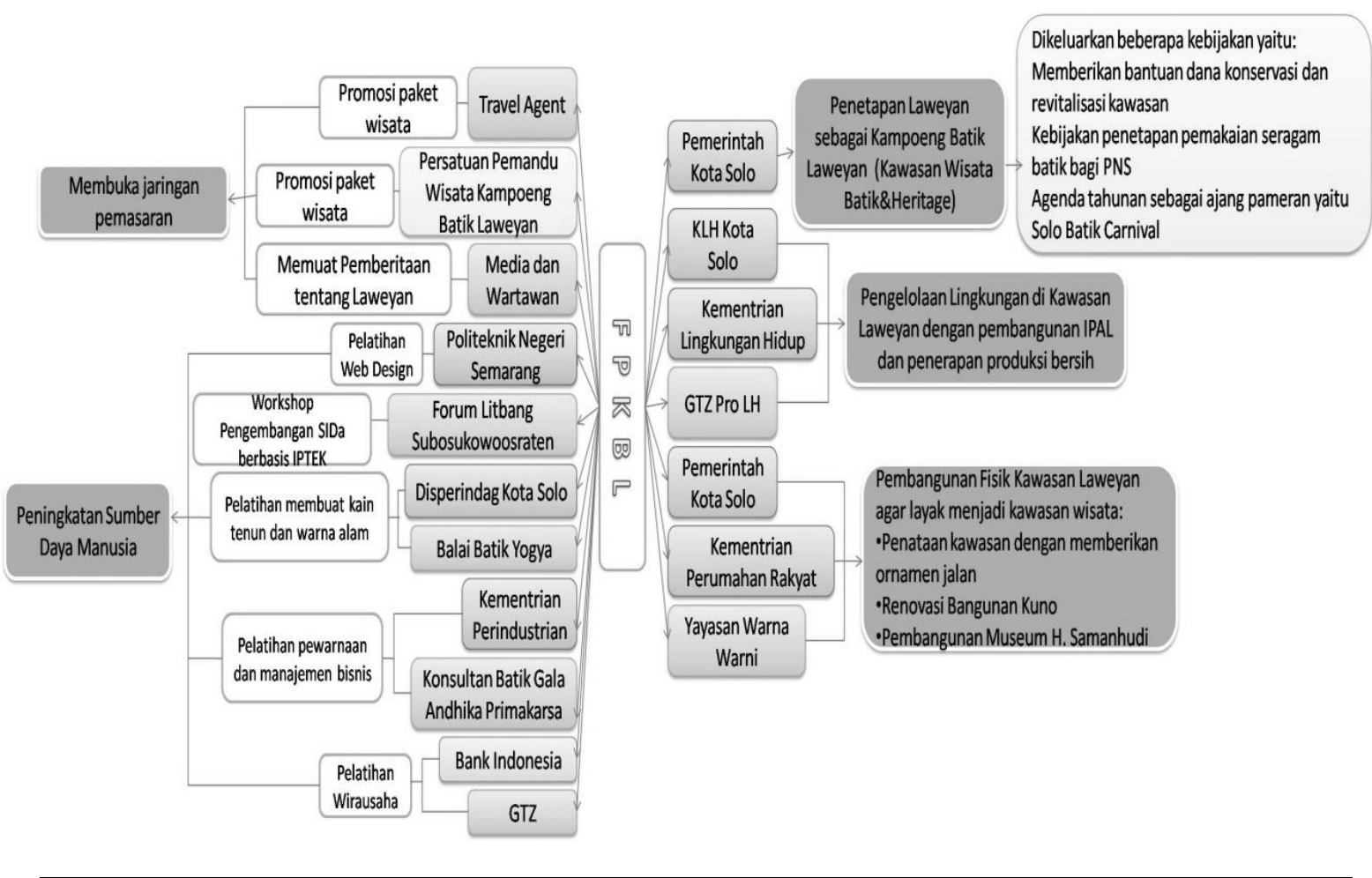

Gambar 11. Jaringan antar Aktor dalam Pengembangan Klaster Batik Laweyan 


\section{Pengaruh Inovasi Kelembagaan Pada Pengembangan Klaster Batik Laweyan Kota Surakarta}

Program-program yang dijalankan oleh FPKBL yang bekerjasama dengan jaringannya memungkinkan terjadinya transfer knowledge yang memberikan pengaruh pada peningkatan kapasitas individu pengusaha batik. Peningkatan kapasitas pengusaha batik dapat dilihat dalam Gambar 12, yang memperlihatkan perubahan dalam pengetahuan, keterampilan dan etos kerja pengusaha. Hal tersebut kemudian berdampak pada terjadinya inovasi dalam usaha batik, yang diperlihatkan dalam Tabel 3.

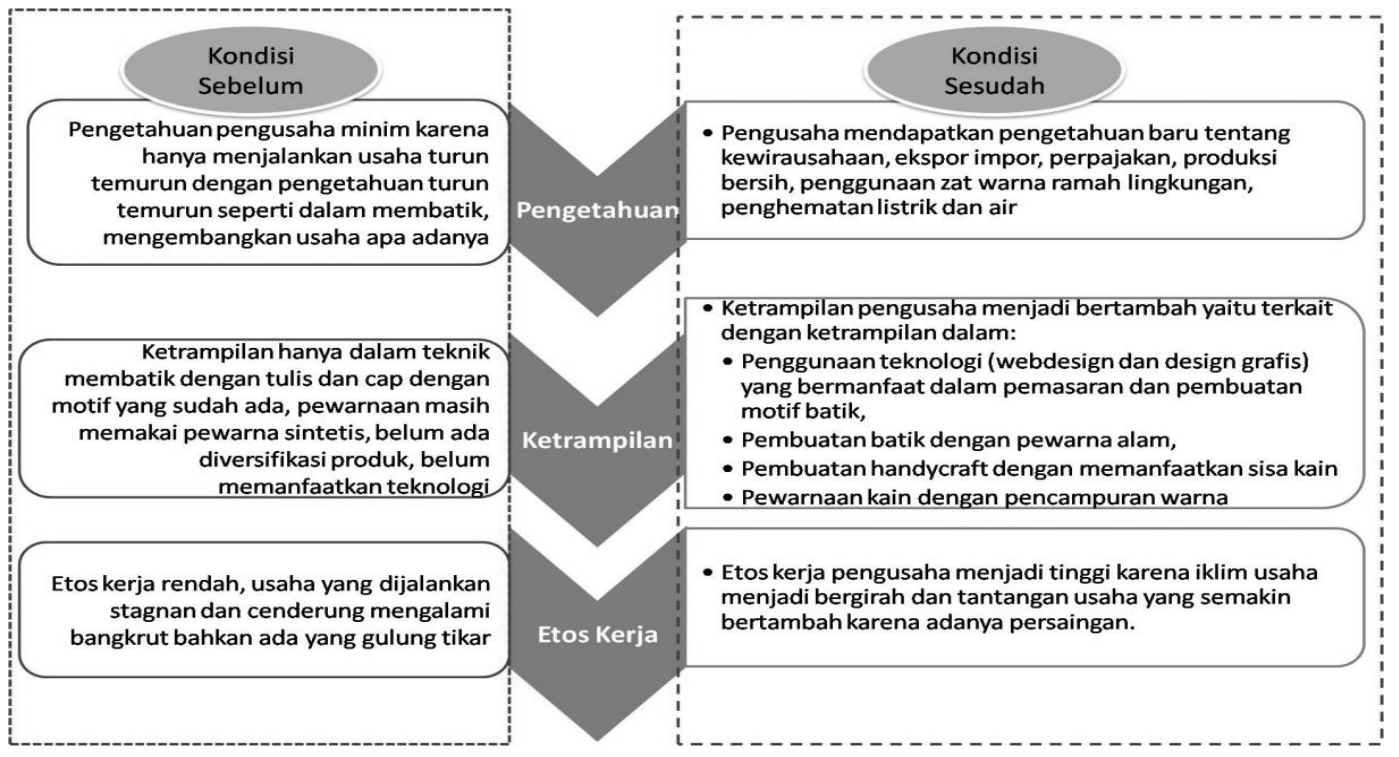

Gambar 12. Inovasi di Tingkat Individu Pengusaha Batik Laweyan

Tabel 3. Matrik Pengaruh Inovasi di Tingkat Individu pada Usaha Batik

\begin{tabular}{|c|c|c|c|c|}
\hline & & Proses Produksi & Produk & Pemasaran \\
\hline \multirow[b]{2}{*}{ 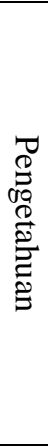 } & $\begin{array}{l}\text { Proses produksi } \\
\text { ramah } \\
\text { lingkungan }\end{array}$ & $\begin{array}{l}\text { - Penggunaan zat warna alam } \\
\text { - Penghematan air dan listrik } \\
\text { - Pemakaian kembali sisa malam } \\
\text { - Produksi bersih }\end{array}$ & $\begin{array}{l}\text { - Pemanfaatan kain } \\
\text { perca } \\
\text { handicraft }\end{array}$ & - \\
\hline & Kewirausahaan & $\begin{array}{l}\text { - Pekerja bertambah disesuaikan } \\
\text { dengan bagiannya (memotong, } \\
\text { membatik, penjualan, penjaga } \\
\text { showroom, bagian keuangan }\end{array}$ & $\begin{array}{ll}\text { - Produk bertambah } \\
\text { tidak hanya kain } \\
\text { tetapi } & \text { juga } \\
\text { pakaian jadi } & \end{array}$ & $\begin{array}{l}\text { - Dulu door to door } \\
\text { sekarang terbuka } \\
\text { melalui pameran dan } \\
\text { media internet } \\
\text { - Membuka showroom } \\
\text { - Pelanggan } \\
\text { bertambah }\end{array}$ \\
\hline \multirow{3}{*}{ 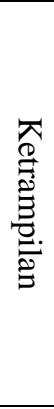 } & $\begin{array}{l}\text { Penggunaan } \\
\text { teknologi }\end{array}$ & $\begin{array}{l}\text { - Pembuatan motif secara digital } \\
\text { - Penggunaan kompor listrik }\end{array}$ & $\begin{array}{l}\text { - Melihat tren mode } \\
\text { pakaian melalui } \\
\text { media internet }\end{array}$ & $\begin{array}{l}\text { - Membuat website } \\
\text { untuk pemasaran }\end{array}$ \\
\hline & $\begin{array}{l}\text { Pencampuran } \\
\text { warna }\end{array}$ & $\begin{array}{l}\text { - Menghasilkan kombinasi } \\
\text { warna baru dari proses } \\
\text { pencampuran warna }\end{array}$ & $\begin{array}{l}\text { - Kain atau pakaian } \\
\text { jadi dengan } \\
\text { kombinasi warna } \\
\text { baru }\end{array}$ & \\
\hline & Handicraft & - Pemanfaatan kain perca & $\begin{array}{l}\text { - Diversifikasi } \\
\text { produk seperti } \\
\text { keset, blankon }\end{array}$ & \\
\hline
\end{tabular}




\section{Kesimpulan}

Kesimpulan dari penelitian yang telah dilakukan adalah adanya inovasi kelembagaan di dalam Klaster Batik Laweyan yang ditunjukkan oleh tumbuhnya rasa nyaman dan saling percaya dalam keterikatan sosial baru antar anggota klaster, antara lain dengan diterimanya atau disepakatinya tujuan bersama Forum Pengembangan Klaster Batik Laweyan (FPKBL) sebagai tatanan/ norma baru dalam kelembagaan pengelolaan batik Laweyan. Sebagai konsekuensinya, upaya pencapaian tujuan oleh anggota dilakukan dengan motivasi yang lebih tinggi. Hal tersebut berpengaruh dalam pengembangan klaster yang ditunjukkan dengan bertambahnya kapasitas anggota untuk bekerja sama, melakukan inovasi usaha baik dalam bahan baku, produksi dan distribusi. Bertambahnya usaha pendukung yang muncul di Laweyan seperti usaha restoran, hotel dan penginapan, home stay dan biro wisata, serta membesarnya jejaring klaster secara eksternal dengan agen-agen perjalanan dan pariwisata, akademis, swasta, LSM dan pemerintah.

\section{Daftar Pustaka}

Andersson, Thomas, dkk. 2004. The Cluster Policy White Book. International Organisation for Knowledge Economy and Enterprise Development (IKED)

Bungin. Burhan. 2006. Metodologi Penelitian Kuantitaif: Komunikasi, Ekonomi, dan Kebijakan Publik serta Ilmu-ilmu Sosial Lainnya. Jakarta: Kencana Prenada Media Group

http://solokotakita.org/atlas/Laweyan.Bahasa.pdf

http://triptourism.com/kampung-batik-laweyan-the-enchanting/kampung-batik-laweyan-set/

Kaplinsky, Raphael dan Morris , Mike. (2000). A Handbook for Value Chain Research. Institute of Development Studies at the University of Sussex and Centre for Research in Innovation Management at the University of Brighton

OECD, 2001. Innovative Clusters - Drivers of National Innovation Systems, Paris

Porter, M.E. (1998) Clusters and the new economics of competition. Harvard Business Review. Boston. Nov/Dec 1998

Rohdewohld, Rainer. 2004. Building Capacity to Support Decentralisation - The Case of Indonesia (1999-2004). Tokyo Symposium on Capacity Development, Tokyo, 4-6 February 2004

Schmitz, Hubert. 2005. Value Chain Analysis for Policy-Makers and Practitioners. International Labour Office. Geneva

Septiningrum, Indah. 2010. Peran Kelembagaan Formal Dalam Pengembangan Ekonomi Lokal Pada Wilayah Berbasis Pertanian Tembakau, Kecamatan Kledung Kabupaten Temanggung. Tesis tidak Diterbitkan. Magister Perencanaan Wilayah dan Kota. UNDIP. Semarang

Sugiyono. 2008. Metode Penelitian Kuantitatif, Kualitatif dan R\&D. Alfabeta. Bandung

Trimurti, Rr. Rigela. 2010. Peran Inovasi dalam Proses Produksi Klaster Industri Kuningan di Kecamatan Juwana Kabupaten Pati. Tugas Akhir tidak diterbitkan. Program Studi Perencanaan Wilayah dan Kota, Fakultas Teknik Universitas Diponegoro

Zallinger, Lucas Von. 2009. Modul Pelatihan Manajemen Klaster. GTZ

Zuhal. 2010. Knowledge and Innovation Platform Kekuatan Daya Saing. Gramedia Pustaka Utama. Jakarta 